\title{
U.S. Consumer Animosity Towards Vietnam: A Comparison Of Generations
}

Joseph P. Little, Saint Louis University, USA

Eldon Little, Indiana University Southeast, USA

K. Chris Cox, Indiana University Southeast, USA

\begin{abstract}
Previous marketing literature suggests that unique marketing strategies are needed for each American generation (Moschis, 2003). The differences between the generational age cohorts are based upon values, preferences, and behaviors unique to each generation and were developed based upon individuals' formative experiences shared as a generation (Smith and Clurman, 1997). While age has been identified as a factor to the development of consumer animosity (Klein and Ettenson, 1999), the question remains: Do older consumers harbor more animosity towards foreign nations? Is it the environment in which each person forms their values, preferences, and behaviors that helps determine their level of animosity? The current study uses a historical context to examine American generations and their animosity towards Vietnam. Results support the hypotheses that American generations do not significantly differ in their levels of animosity towards Vietnam. The findings suggest that age has a spurious correlation with the development of consumer animosity.
\end{abstract}

Keywords: Age, consumer animosity, consumer behavior, country of origin, cross cultural, generations, international marketing, Vietnam

\section{INTRODUCTION}

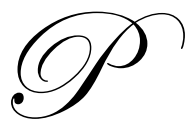

revious marketing literature suggests that unique marketing strategies are needed for each American generation (Moschis, 2003). The differences between the Depression (born between 1925 and 1945), Baby Boomer (born between 1946 and 1964), Generation X (born between 1965 and 1976), and Generation Y (born between 1977 and 1994) (Hawkins et al., 2003) age cohorts are based upon values, preferences, and behaviors unique to each generation and were developed based upon individuals' formative experiences shared as a generation (Smith and Clurman, 1997). While age has been identified as a factor to the development of consumer animosity (Klein and Ettenson, 1999), the question remains: Do older consumers harbor more animosity towards foreign nations? Is it the environment in which each person forms their values, preferences, and behaviors that helps determine their level of animosity?

The current study examines how these unique generational formative experiences affect the American consumer's animosity towards Vietnam. Answering the call to examine consumer animosity in a historical context (Amine et al., 2005) the generational age cohorts are used as a proxy for values and dispositions that help determine a consumer's animosity towards Vietnam and the willingness to buy Vietnamese products. The contribution of the research is to place American consumer animosity in a historical context in order to shed light on how environment and context lead to differences in attitudes towards foreign countries and their products.

First, the study reviews the consumer animosity and generational differences literature. Next, we examine the relationship between the United States and Vietnam. The paper focuses on the environment of the U.S. during each generational age cohort and the U.S./Vietnam relationship during those years. Based on the literature and historical examination we develop hypotheses. Third, we lay out our methodology for testing the hypotheses. Finally, results are discussed and the study concludes with a discussion of the findings along with their implications. 


\section{CONSUMER ANIMOSITY}

Previous literature has defined animosity as anger directed at a particular country due to political, economic, diplomatic, or military events (Klein et al., 1998). More recent literature has looked at other antecedents to the development of animosity. Also, personal characteristics such as age, patriotism, and prejudice have been suggested as antecedents to animosity (Klein and Ettenson 1999). Regardless of the cause of the animosity, previous literature demonstrates that a firm's sales can be damaged by consumers' animosity towards the firm's home country (Riefler and Diamantopoulos, 2007).

Klein et al. (1998) was the first study to link consumer animosity to the willingness of the consumer to purchase products from the nation for which the animosity is focused. Using the background of the Nanjing massacre (300,000 Chinese died), Klein et al. showed that animosity had a negative impact on Chinese consumers purchasing Japanese products. However, the research also suggested that feelings of animosity did not affect the quality perceptions of the Japanese products. Feelings of animosity affect purchase decisions directly.

The finding that animosity affected purchase decisions separately from product quality judgments challenged the findings from previous country-of-origin literature (Riefler and Diamantopoulos, 2007). Country-oforigin literature had suggested that $\mathrm{COO}$ affects purchase decisions through product judgments (Bilkey and Nes, 1982; Liefeld, 1993). So, consumer animosity may act as a direct independent variable instead of a moderating variable of product quality perceptions.

Subsequent studies to Klein et al. (1998) have shown that animosity and ethnocentrism are distinct constructs (Klein and Ettenson, 1999; Witkowski, 2000; Hinck, 2004). Animosity indeed has independent effects on consumers' willingness to buy a product. Comparing animosity to ethnocentrism, research suggests that consumers who are ethnocentric are unwilling to buy products from any foreign nation because ethnocentric consumers feel that it is wrong or even immoral to purchase a foreign nation's products (Shimp and Sharma, 1987). Consumer animosity, however, affects only purchase decisions for products from the nation for which the animosity is directed. Since Klein et al.'s (1998) study subsequent research has studied animosity in other contexts. Much of the research studied animosity in less extreme contexts (Shin, 2001; Klein, 2002) because the Nanjing massacre is such an extreme antecedent to the development of animosity. Also, Amine et al. (2005) reviewed animosity research with a focus on managerial implications instead of focusing on the conceptualization or measurement of the animosity construct.

Riefler and Diamantopoulos (2007) categorize previous consumer animosity studies into three categories. The first group of research is the original papers that contributed to the theoretical foundation of the animosity construct. The second group of research consists of replications of the original animosity research provided by Klein et al. (1998) that sought to validate the behavioral impact of the consumer animosity construct. The third group of research focuses on extending the applicability of the animosity construct. For example, Hinck (2004) studied "domestic animosity", looking at the impact of inter-border tensions on buying behavior. Also, Shoham (2006) studies inter-ethnic animosity between Jewish and Arab Israelis. These more recent studies that attempt to extend the animosity construct supports our suggestion of a need of a broader consumer animosity model.

In addition to applying the animosity framework to more contexts, previous research has focused on distinguishing different types of animosity. Ang et al. (2004) developed a taxonomy of four types of animosities that distinguish between stable versus situational and between national versus personal animosities. Stable animosities are animosities that are based on a historical perspective, while situational animosities are animosities that are situation specific and are temporary. National animosities are those feelings based on a macro-level perspective, such as a military occupation of a country. Personal animosities are those animosities that are based on an individual's personal experience, such as the perception of losing a job due to the outsourcing of jobs to another country.

The Nanjing massacre study (Klein et al., 1998) is a demonstration of stable animosity. The Chinese have had a long lasting, enduring animosity directed at Japan for more than 50 years (the Nanjing massacre took place in 1937). A more recent longitudinal study (Ettenson and Klein, 2005) provided evidence for situational animosity. 
The Ettenson and Klein research measured animosity levels of Australian consumers at two points in time. The first time point was during France's nuclear testing in the South Pacific which caused tensions between the two nations. The second measurement of animosity took place one year later after the nuclear testing had been stopped. The findings showed that the level of consumer animosity had decreased within the one year period. Not only did the Ettenson and Klein study demonstrate that temporary animosity exists, providing evidence that Ang et al.'s (2004) refinement of the animosity construct was warranted, it also provided evidence that Amine et al.'s (2005) suggestion that a historical perspective and contextual understanding is needed in order to distinguish between the different types of consumer animosity.

Previous research dealing with consumer animosity provides various sources of animosity. In Klein et al.'s (1998) original study of animosity the authors distinguish between war-based and economic-based animosity as did subsequent animosity research, until Jung et al. (2002) further distinguished types of animosity. Economic-based animosity stems from such things as a perception of unfair trading practices, or the economic power of a nation. War-based animosity stems from a more historical base of military related actions (such as the Nanjing massacre). A third type of animosity that has been examined is a political/diplomatic antecedent to the development of animosity, such as the animosity between French and American consumers (Russell, 2004). At this point it appears that research suggests that war-based animosity appears to be more enduring, while economic- or political-based animosity seems to be more temporary, although the case of French and American animosity may be an exception to this rule, as it appears that animosity between the two has been enduring while the two have never been at war.

The Klein et al. (1998) study showed that war-based, economic-based, or overall animosity (animosity measured without distinguishing the sources of the negative feeling) all have an negative impact on the willingness of the consumer to purchase a product from the country in which the consumer has feelings of animosity. However, the study also suggested that consumers were able to objectively evaluate the quality of the product as earlier mentioned.

Multiple antecedents to the development of consumer animosity have been shown in previous literature. The antecedents can be classified as war-, economic-, social/ cultural-, and personal-based (Riefler and Diamantopoulos, 2007). Along with consumer animosity antecedents, subjective norms such as patriotism, nationalism, and collectivism have been shown to affect how consumers use their animosity in their purchase intentions (Riefler and Diamantopoulos, 2007; Klein and Ettenson, 1999; Shoham et al., 2006).

The majority of consumer animosity research has focused on beliefs about a country-of-origin as the central antecedent to the development of animosity. Consumer's build ill feelings towards a country-of-origin based on war, economic, social/cultural, and personal experience indiscretions. War indiscretions may be war atrocities committed by a country such as the Nanjing massacre (Klein et al., 1998). War-based consumer animosity is a more stable, long lasting animosity that can be passed down from generation to generation (Jung et al., 2002; Ang et al., 2004). Therefore, American animosity towards Vietnam developed due to the Vietnam conflict would be long lasting and passed down from generation to generation.

Economic animosity is concerned with a country's economic policies, power, and suffering. Some Asian consumers and governments have blamed the United States for their economic crisis which caused great economic suffering. During the crisis businesses collapsed and many workers within East Asia lost their jobs. Some Asians felt that because of the United States economic power and their interference in the economic practices in Asia they were to blame for the crisis causing a rise in anti-American sentiment among Asian consumers (Ang et al., 2004).

Social/Cultural differences between countries have also been suggested as an antecedent to consumer animosity (Riefler and Diamantopoulos, 2007). Religious differences, mentality differences, and cultural imperialism can lead to increased consumer animosity. Taking a historical perspective as suggested by Amine et al. (2005), we can see that French anti-Americanism is due partly to the United States cultural imperialism of France and mentality differences between the two nations. First, the French, being extremely proud of their culture, have made a national hero of Jose Bove for bashing McDonalds, a symbol of American cultural imperialism. Resentment of the perceived "McDonaldization" of their culture runs high in France. The influential daily Le Monde, for example, warns that McDonald's insidious behavior may ruin sacred reflections of French identity (Karon, 2004). 
Also, when denouncing America many French focus on mentality differences between France and the United States by mentioning America's social order and values prevalent in the United States (Meunier, 2006).

Negative personal experiences with a country-of-origin can also cause consumer animosity. Jung et al. (2002) developed a typology of different manifestations of animosity. One type was personal animosity. The authors found that animosity towards a country can be sparked by a particular episode, or developed over several episodes over time which creates a longer-lasting emotion. The former is considered a situational animosity, while the latter is considered a stable animosity. Situational animosity refers to strong emotions that are associated to a specific circumstance (Jung et al. 2002). Also, situational animosity can become a more stable animosity if it evolves into a more general dislike toward a country. According to Jung et al. (2002), animosity is a network of angry feelings that are linked to memories.

Subjective norms, or reference group influences that the consumer considers, affect behavioral intention (Fishbein and Azjen, 1975). Marketers have generally accepted that reference group influence is important in at least some types of consumer decision making (Bearden and Etzel, 1982). Witt (1969), in a consumer brand choice study, found that group cohesiveness, which cultural beliefs such as patriotism, nationalism, and collectivism are closely tied, influences behavior (Bearden and Etzel, 1982). The more group cohesiveness a consumer believes to be involved, the more influence the group has upon brand choice decisions. By using prominent reference group members, or alluding to reference groups in persuasive marketing attempts, marketers demonstrate the belief that reference groups generate pressure for conformity to group, or subjective norms.

A consumer whose cultural beliefs include a high group cohesiveness, such as being highly patriotic, nationalistic, and highly collective in evaluating a behavior, will consider the reference group influences, or subjective norms more than a consumer who is less patriotic, nationalistic, or collectivistic. As consumers we regard possessions as a part of ourselves (Belk, 1988). Consumers use their possessions as an extension of themselves. Consumers allow their possessions to reflect who they are. Money allows consumers to selectively purchase or reject a product, thereby more selectively shaping the extended self (Belk, 1988). So, if a consumer has the volitional control to purchase or not purchase a product, they have the ability to shape how others see them by shaping their extended self. The consumer's evaluation of the consequences of a behavior due to social pressures, or subjective norms, help determine a consumer's behavioral intention.

\section{GENERATIONAL DIFFERENCES}

The development of beliefs about countries-of-origin, cultural beliefs, and pressures provided by subjective norms are affected by the environment for which a person is exposed. American consumers differ in the individuals' formative experiences shared as a generation (Smith and Clurman, 1997). For example, the environment experienced by those of the Depression generation differs considerably from the environment experienced by the Generation Y cohort. Therefore, individuals of different generations may have considerable differences in their beliefs about foreign countries, their own cultural beliefs, and pressures provided by subjective norms.

\section{A GENERATIONAL PERSPECTIVE AND THE U.S./VIETNAM RELATIONSHIP}

\section{The Depression Generation}

Born from 1925 to 1945 (Hawkins et al., 2003), the Depression Generation's formative years were in an environment of economic depression and then of war. By the late 1920s the U.S. had become a consumer society, where not only could individuals afford the means of subsistence, but also discretionary goods and services (Brinkley, 1993). However, in October of 1929 the stock market crashed sending the United States into the Great Depression for which the nation would stay for approximately ten years. The American gross national product fell from $\$ 104$ billion in 1929 to $\$ 76.4$ billion in 1932. Individual American bank depositors lost over $\$ 2.5$ billion as many banks went bankrupt or closed their doors to avoid bankruptcy. Unemployment skyrocketed throughout the nation. For instance, Ohio's major cities had unemployment rates as high as 80\% (Brinkley, 1993). However, the economic struggles did not change the teachings of a "success ethic," that every individual can work hard and 
advance in the American Society (Brinkley, 1993). International trade was a major factor that was blamed for the Great Depression. The international demand for American exports had dropped. Eventually, because international trade was blamed, the U.S. became more protectionistic (Brinkley, 1993).

World War II ended the Great Depression at last. The war caused a great movement towards patriotism and pride in the United States as American citizens banned together to fight off communism (Brinkley, 1993). The result of World War II left the United States as the most powerful country in the world (Brinkley, 1993).

The formative years of the depression generation included a rejuvenation of both the economic and military power of the United States, along with experiencing the pains of economic depression and war. There was not a well known relationship between the U.S. and Vietnam.

\section{The Baby Boomer Generation}

The birth rate in the U.S. exploded after World War II resulting in the Baby Boomer Generation (Born between 1946 and 1964) (Hawkins et al., 2003). Also, around 1948 the third phase of globalization began due to the development of GATT (General Agreement on Tariffs and Trade) lowering barriers to international trade, and the Marshall Plan that was meant to rebuild Europe and repel communism after World War II (Cavusgil, 2007).

The Cold War had profound effects on American domestic life producing the most corrosive outbreak of antiradical hysteria in the history of the country (Brinkley, 1993). The Baby Boomer generation's formative environment was made up of a dichotomy of the prosperous expansion of international trade and increased globalization against the protectionism of antiradical thinking produced by the fear of the communism. The growth of the middle class that resulted in the United States achieving the highest standard of living of any society in the history of the world (Brinkley, 1993) drove discretionary spending. U.S. imports totaled over $\$ 30$ billion for the first time in 1965 (U.S. Census Bureau, 2008).

France and the communist led Viet Minh had fought an eight year guerilla war until a cease fire agreement was signed in 1954. While the United States witnessed the agreement they did not sign the agreement which split the country of Vietnam at the $17^{\text {th }}$ parallel into the communist north and the Republic south(U.S. State Department, 2008). In the late 1950s the North reactivated a network of communist guerillas in the South referred to as the Viet Cong. The Viet Cong led an armed campaign against Southern officials and villagers. At the request of the South Vietnamese President Ngo Dinh Diem, U.S. President John F. Kennedy sent military advisors to South Vietnam to help the government deal with the Viet Cong. Due to increasing political turmoil in the south U.S. military increased its presence in 1963 (U.S. State Department, 2008).

\section{Generation X}

As the Vietnam War began Generation X consumers were being born (born between 1965 and 1976) (Hawkins et al., 2003). In 1965, U.S. President Lyndon Johnson sent the first U.S. combat troops to Vietnam. The peak number of U.S. troops reached 534,000 in 1969. The Paris Peace Accords was signed in 1973 ending the official American combat role in Vietnam. Finally, as Saigon fell in 1975 the last U.S. soldier is killed in the Vietnam conflict and Vietnam falls under the control of the communists (U.S. State Department, 2008). Approximately three to four million Vietnamese and 58,000 Americans were killed during the conflict (vietnamwar.com, 2008).

The Vietnam conflict, along with the Civil Rights movement, began the social revolution against the authoritative figures made up of previous generations. Generation $\mathrm{X}$ consumers grew up in an environment of domestic social change and liberalization and continued globalization and international trade. For the first time the balance of trade of the United States (Balance of Payments) became negative. The U.S. was importing more than it was exporting by 1971(U.S. Census Bureau, 2008). 


\section{Generation Y}

During Generation Y's (born between 1977 and 1994) (Hawkins et al., 2003) formative years the U.S. placed an embargo against Vietnam in 1979 then eventually lifted it in 1992 (U.S. State Department, 2008) even though Vietnam is still led by the Communist Party. However, communism is no longer the great fear of Western society. Generation Y consumers no longer read news stories, or hear Presidential speeches on the evils of communism, the subject is now the evils of terrorism (Bush, 2005). In the 1990s the U.S. started to invest and trade again with Vietnam.

\section{HYPOTHESES}

Based on the American environment during each of the generation's formative years and the consumer animosity literature review, the following hypotheses are proposed. We find that outside the Vietnam conflict there is little link between U.S. consumers and Vietnam. Since war-based animosity is long lasting and passed down from generation to generation (Jung et al., 2002; Ang et al., 2004) we hypothesize that age, or generational age cohort, has little affect on American's level of animosity towards Vietnam. Therefore:

H1: The Depression Generation consumers do not have significantly higher levels of animosity towards Vietnam than later generations.

H2: The Baby Boomer Generation consumers do not have significantly higher levels of animosity towards Vietnam than later generations.

H3: The Generation $X$ consumers do not have significantly higher levels of animosity towards Vietnam than Generation $\mathrm{Y}$ consumers.

\section{METHODOLOGY}

A sample of American consumers was gathered by undergraduate business students at a medium sized Midwestern university in connection to a class project on developing marketing strategies for different generations. Each student was asked to collect a sample of two respondents from each of the four generations (one male and one female). Each respondent, while being kept confidential, was asked to also give a telephone number or an email address. After surveys were collected $10 \%$ of respondents were contacted to verify that they did indeed complete the questionnaire. This procedure has been used in previous marketing literature to provide confidence in the sample and avoid students simply filling out the questionnaires themselves (Bitner et al., 1990).

The respondents in each generation completed a questionnaire using a modified animosity measure using both war-based and general animosity items developed by Klein et al. (1998). Along with the animosity instrument, demographic items (gender, household income, and level of education) that have been found to affect consumer animosity levels (Klein et al, 1998; Klein and Ettenson, 1999; Riefler and Diamantopoulos, 2007) were also included in order to control for confounding variables and create homogenous groups. While the collection procedure may not be conducive to providing external validity, it is only necessary to provide internal validity in a rigorous theoretical test. Controlling for, instead of varying and examining, background factors is encouraged for theoretical research (Calder et al., 1982). The data collection procedure resulted in 197 useable questionnaires with generation group sample sizes of 30 or more allowing the use of ANCOVA and post hoc analysis to examine the differences between each specific generation. A one-way ANCOVA allows researchers to examine group differences while controlling for confounding variables. The research design uses generation membership as the independent categorical variable and the mean scores of the animosity measure as the dependent variable.

\section{RESULTS}

First, the internal reliability of the animosity measurement was tested and was found to be satisfactory with a Cronbach's Alpha of .887. Next, an examination of the means took place. Table 1 shows descriptive statistics of each generation including means, standard deviations and group sample sizes. 
Table 1. Descriptive Statistics

Dependent Variable: Animosity

\begin{tabular}{|c|c|c|c|}
\hline Generation & Mean & Std. Deviation & N \\
\hline Depression & 12.0870 & 5.48058 & 46 \\
\hline Baby Boomer & 10.3958 & 5.15603 & 48 \\
\hline Generation X & 8.5094 & 4.50906 & 53 \\
\hline Generation Y & 8.8400 & 4.17162 & 50 \\
\hline Total & 9.8883 & 5.00079 & 197 \\
\hline
\end{tabular}

The mean of each generation's animosity does decrease until Generation Y. Meaning that Generation Y actually harbors a higher level of animosity than the generation before it. However, the estimated means using the covariates are shown in Table 2.

Table 2. Estimates

Dependent Variable: Animosity

\begin{tabular}{|c|c|c|c|c|}
\hline \multirow{2}{*}{ Generation } & \multirow{2}{*}{ Mean } & \multirow{2}{*}{ Std. Error } & \multicolumn{2}{|c|}{ 95\% Confidence Interval } \\
\cline { 3 - 5 } & & .717 & 9.754 & Upper Bound \\
\hline Depression & $11.168(\mathrm{a})$ & .673 & 9.294 & 12.583 \\
\hline Baby Boomer & $10.621(\mathrm{a})$ & .646 & 7.710 & 11.948 \\
\hline Generation X & $8.985(\mathrm{a})$ & .663 & 7.658 & 10.260 \\
\hline Generation Y & $8.965(\mathrm{a})$ & .50 .272 \\
\hline
\end{tabular}

a Covariates appearing in the model are evaluated at the following values: Gender $=.5076$, Income $=3.0457$, Education $=$ 3.3503.

The ANCOVA is significant $(F=6.427, p=.000)$ indicating that there is at least one significant difference of animosity level between the generational age cohorts. However, post hoc pairwise comparisons were used to test the hypotheses. The Least Significant Difference (LSD) procedure was used to test individual hypotheses. Table 3 shows the results of the pairwise comparisons.

The results indicate that the Depression generation does harbor significantly higher levels of animosity towards Vietnam than does Generation X and Generation Y. However, in partial support of Hypothesis 1, there is not a significant difference between the animosity level of the Depression generation and the Baby Boomer generation. An explanation for the Depression generation showing higher levels of animosity towards Vietnam than both Generation X and Y could be the way the Depression generation looks at communism. As President Bush stated in 2005, today we look at terrorism as evil, but during the Depression generation's formative years communism was the source of evil. In support of Hypothesis 2, the Baby Boomer generation does not harbor higher levels of animosity towards Vietnam than all later generations. There is also no significant difference between Generation X and Generation $\mathrm{Y}$, in support of Hypothesis 3. Therefore, it looks as though animosity towards Vietnam was passed down from generation to generation since Generation $\mathrm{Y}$ was born after the Vietnam conflict had ended.

\section{CONCLUSION}

While age has been identified as a determinant of consumer animosity (Klein and Ettenson, 1999), the reasons behind why age is a determinant have yet to be established. According to Smith and Clurman (1997) consumers develop values, preferences, and behaviors based upon individuals' formative experiences shared as a generation. Following the suggestion for the investigation of the historical contexts surrounding the development of consumer animosity (Amine et al., 2005), the presented research looked to examine how the environment each generation encountered during their formative years help shape their feelings of animosity towards Vietnam. As consumer animosity has been shown to have a direct effect on purchase intentions for products from the country in which the animosity is directed (Klein et al., 1998), we find that it is important to uncover the reasons behind why and how animosity is developed. 
Because animosity is based on specific events, such as the Vietnam conflict or the Nanjing Massacre, an examination of animosity must be placed in context. While previous literature has found that older consumers harbor higher levels of animosity, our findings suggest that age has a spurious relationships with consumer animosity. Our findings suggest that it isn't the age of an individual, but the experiences of the individual that leads to the development of animosity. Finally, while this study focused on a war-based source for the development of animosity, we suggest that future research should examine differing sources of animosity, such as economic-based animosity, while embedding the empirical findings within a historical examination.

For the practitioner the following are findings that should be applied:

- Consumer animosity has significant effects on a consumer's willingness to buy products from a firm associated with the offending country.

- Older generations may have a significant influence on the perceptions and purchase intentions of younger generations.

- $\quad$ Firms with products made in Vietnam should be careful in the promotion of the product's country-oforigin, as U.S. consumers still harbor animosity towards the country based on the Vietnam conflict.

- Managers should not assume indiscretions have been forgiven simply because time has passed. Indiscretions may still have a significant effect on consumers' purchasing intentions years after the occurrence of negative events.

Table 3. Pairwise Comparisons Dependent Variable: Animosity

\begin{tabular}{|c|c|c|c|c|c|c|}
\hline \multirow[t]{2}{*}{ (I) Generation } & \multirow[t]{2}{*}{ (J) Generation } & \multirow[t]{2}{*}{$\begin{array}{c}\text { Mean } \\
\text { Difference (I-J) }\end{array}$} & \multirow[t]{2}{*}{ Std. Error } & \multirow[t]{2}{*}{ Sig.(a) } & \multicolumn{2}{|c|}{$\begin{array}{l}\text { 95\% Confidence Interval } \\
\text { for Difference (a) }\end{array}$} \\
\hline & & & & & Lower Bound & Upper Bound \\
\hline \multirow[t]{3}{*}{ Depression } & Baby Boomer & .547 & .989 & .581 & -1.404 & 2.498 \\
\hline & Generation X & $2.183(*)$ & .990 & .029 & .230 & 4.137 \\
\hline & Generation Y & $2.203(*)$ & .990 & .027 & .251 & 4.155 \\
\hline \multirow[t]{3}{*}{ Baby Boomer } & Depression & -.547 & .989 & .581 & -2.498 & 1.404 \\
\hline & Generation X & 1.636 & .929 & .080 & -.197 & 3.470 \\
\hline & Generation Y & 1.656 & .949 & .083 & -.216 & 3.528 \\
\hline \multirow[t]{3}{*}{ Generation X } & Depression & $-2.183(*)$ & .990 & .029 & -4.137 & -.230 \\
\hline & Baby Boomer & -1.636 & .929 & .080 & -3.470 & .197 \\
\hline & Generation Y & .020 & .920 & .983 & -1.794 & 1.833 \\
\hline \multirow[t]{3}{*}{ Generation Y } & Depression & $-2.203(*)$ & .990 & .027 & -4.155 & -.251 \\
\hline & Baby Boomer & -1.656 & .949 & .083 & -3.528 & .216 \\
\hline & Generation X & -.020 & .920 & .983 & -1.833 & 1.794 \\
\hline
\end{tabular}

Based on estimated marginal means

* The mean difference is significant at the .05 level.

\section{AUTHOR INFORMATION}

Joseph Little is a PhD student with a concentration in International Business and Marketing at Saint Louis University. He has presented research at the AMA annual conference and AIB annual conference. His research interests are cross cultural consumer behavior focusing on consumer animosity and consumer ethnocentrism.

Eldon Little is Professor of Marketing, Indiana University Southeast. He received his $\mathrm{PhD}$ from the University of Nebraska-Lincoln. He has published in a variety of journals including Public Opinion Quarterly, Strategic Management Journal and the Journal of the Academy of Marketing Science.

Chris Cox is an Associate Professor of Business at Indiana University Southeast. His research interests include the dynamics of buyer-seller relationships, persuasive processes, internet-based marketing communications. His 
research has appeared in Communication Monographs, Journal of Promotion Management, Industrial Management and Data Systems among others.

\section{REFERENCES}

1. Amine, L., Chao, M. and Arnold, M. (2005), "Executive insights: exploring the practical effects of country of origin, animosity, and price-quality issues - two case studies of Taiwan and Acer in China", Journal of International Marketing, Vol. 13, No. 2, pp.114-50.

2. Ang, S.H., Jung, K., Kau, A.K., Leong, S.M., Pornpitakpan, C. and Tan, S.J. (2004), “Animosity towards economic giants: what the little guys think", The Journal of Consumer Marketing, Vol. 21, Nos 2/3, pp.190-207.

3. Bearden, W.O. and Etzel, M.J. (1982), "Reference Group Influence on Product and Brand Purchase Decisions", Journal of Consumer Research, Vol. 9, September, pp. 183-194

4. Belk, R.W. (1998), "Possessions and the Extended Self", Journal of Consumer Research, Vol. 15, September, pp. 139-68.

5. Bilkey, W. and Nes, E. (1982), “Country-of-origin effects on product evaluations”, Journal of International Business Studies, Vol. 13, No. 1, pp.89-99.

6. Bitner, M.J., Booms, B.H., and Tetrault M.S. (1990), "The Service Encounter: Diagnosing Favorable and Unfavorable Incidents", Journal of Marketing, Vol. 54(January), pp. 71-84.

7. Brinkley, A. (1993), The Unfinished Nation: A Concise History of the American People Vol. Two: From 1865, U.S.A., McGraw-Hill, Inc.

8. Bush, G.W. (2005), "President Discusses War on Terror at National Endowment for Democracy", http://www.whitehouse.gov/news/releases/2005/10/20051006-3.html, Accessed April 28, 2008.

9. $\quad$ Calder, B.J., Phillips, L.W., Tybout, A.M. (1982), "The Concept of External Validity", Journal of Consumer Research, Vol. 9 (December), pp.240-244.

10. Cavusgil, S.T. (2007), "Themes and Resources for Teaching International Business", $7^{\text {th }}$ Biennial International Business Institute for Community College Faculty.

11. Ettenson, R. and Klein, G. (2005), "The fallout from French nuclear testing in the South Pacific - a longitudinal study on consumer boycotts", International Marketing Review, Vol. 22, No. 2, pp. 199-224.

12. Fishbein, M. and Azjen, I. (1975), Belief, attitude, intention, and behavior: An introduction to theory and research. Reading, MA: Addison-Wesley.

13. Hawkins, D.I., Best, R.J., and Coney, K.A. (2003), Consumer Behavior: Building Marketing Strategy, $9^{\text {th }}$ Edition, U.S.A: Irwin Professional Publishing.

14. Hinck, W. (2004), "The role of domestic animosity in consumer choice: empirical evidence from Germany", Journal of Euro-Marketing, Vol. 14, Nos. 1/2, pp. 87-104.

15. Jung, K., Ang, S.H., Leong, S.M., Tan, S.J., Pornpitakpan, C., and Kau, A.K. (2002), “A typology of animosity and its cross-national validation”, Journal of Cross-Cultural Psychology, Vol. 33, No. 6, pp.52939.

16. Karon, T. (2004), “Adieu, Ronald McDonald”, www.time.com, http://www.time.com/time/columnist/karon/article/0,9565,196925,00.html, Accessed on January 4, 2008.

17. Klein, J., Ettenson, R., and Morris, M. (1998), "The animosity model of foreign product purchase: an empirical test in the People's Republic of China", Journal of Marketing, Vol. 62, pp.89-100.

18. Klein, J. and Ettenson, R. (1999), "Consumer animosity and consumer ethnocentrism: an analysis of unique antecedents", Journal of International Consumer Marketing, Vol. 11, No. 4, pp.5-24.

19. Klein, J. (2002), "Us versus them, or us versus everyone? Delineating consumer aversion to foreign goods", Journal of International Business Studies, Vol. 33, No. 2, pp.345-63.

20. Liefeld, J. (1993), "Experiments on country-of-origin effects: review and meta-analysis of effect size", in Papadopoulos, N. and Heslop, A. (Eds), Product-Country Image - Impact and Role in International Marketing, International Business Press, New York, NY, pp.117-56.

21. Meunier, Sophie (2005), "Anti-Americanisms in France", Council for European Studies at Columbia University Website, www.councilforeuropeanstudies.org/pub/Meunier_jan05.html.

22. Moschis, G. P. (2003), "Marketing to Older Adults: An Updated Overview of Present Knowledge and Practice", The Journal of Consumer Marketing, Vol. 20, Iss. 6, pp. 516-525. 
23. Riefler, P. and Diamantopoulos, A. (2007), "Consumer animosity: a literature review and a reconsideration of its measurement", International Marketing Review, Vol. 24, No. 1, pp.87-119.

24. Russel, C.A. (2004), Now Showing: Global Movies Crossing Cultural Lines. Is Resistance Futile?, CIBER working paper series, San Diego State University, San Diego, CA.

25. Shimp, T. and Sharma, S. (1987), "Consumer ethnocentrism: construction and validation of the CETSCALE”, Journal of Marketing Research, Vol. 24, pp. 280-9.

26. Shin, M. (2001), "The animosity model of foreign product purchase revisited: does it work in Korea?", Journal of Empirical Generalisations in Marketing Science, Vol. 6, pp.6-14.

27. Shoham, A., Davidow, M., Klein J., and Ruvio, A. (2006), "Animosity on the Home Front: The Intifada in Israel and its impact on Consumer Behavior", Journal of International Marketing, Vol. 14(3), pp. 92-114.

28. Smith, J.W. and Clurman A. (1997), Rocking the Ages: The Yankolvich Report on Generational Marketing, New York, NY: HaperCollins Publishers.

29. U.S. Census Bureau (2008), "U.S. Trade in Goods and Services", http://www.census.gov/foreigntrade/balance/c5700.html\#2000, Accessed April 24, 2008.

30. U.S. State Department (2008), "Background Note: Vietnam”, http://www.state.gov/r/pa/ei/bgn/4130.htm, Accessed September 10, 2008.

31. Vietnamwar.com (2008), "Vietnam War History: Past, Present, and Future", http://vietnamwar.com/warhistory.htm, Accessed September 10, 2008.

32. Witkowski, T. (2000), "Effects of animosity toward China on willingness to buy Chinese products", in McClean, G., Kaynak, E. and Aliaga, O. (Eds), Managing in a Turbulent International Business

Environment, The International Management Development Association, Hummelstown, PA, pp.470-7.

33. Witt, R.E. (1969), "Informal Social Group Influence on Consumer Brand Choice", Journal of Marketing Research, Vol. 6, pp. 473-477. 